ISSN 1598-0170 (Print)

ISSN 2287-1136 (Online)

http://www.jksii.or.kr

\title{
$\mathrm{N}-\mathrm{Screen}$ 환경 기반의 이러닝 시스템 설계 방안
}

\section{Design of e-Learning System in N-Screen Environment}

\author{
신 유 진* \\ Yu-jin Shin
}

\author{
서 동 수** \\ Dongsu Seo
}

\author{
홍 승 필*** \\ Seng-phil Hong
}

\section{요 약}

지능형 모바일 및 가전기기의 등장은 다양한 멀티미디어 콘텐츠 뿐 아니라 교육용 콘텐츠의 이용량을 증대시켰다. 특히 이동성을 강조한 단말 기기인 스마트폰과 스마트패드의 보급 및 지능화된 스마트 $\mathrm{TV}$ 의 등장은 다양한 단말 환경에서 편리하게 학습할 수 있는 환경을 제공하였고, 언제 어디서나 이용자가 교육용 콘텐츠를 이용할 수 있도록 했다. 그러나 현재 이용되고 있는 스마트 디바이스들 은 단말 제조사 및 모바일 OS 공급자의 정책이 통일되지 않아 다양한 환경 내에서의 콘텐츠의 재사용이 어렵다. 이에 본 논문에서는 이러한 문제점을 해결하기 위해 NeS(N-Screen e-learning System)를 제안하고자 한다. NeS는 이용자 학습 관리, 교육 콘텐츠 관리의 교육 관련 시스템과 콘텐츠 변환과 양방향 처리로 이루어지는 N-Screen 대응 콘텐츠 전송 시스템으로 구성된다. NeS에서는 새로운 웹 표준으로 각광받고 있는 HTML 5 언어를 이용해 각종 기기간의 상호호환성을 보장한다. 본 논문에서 제시하는 NeS를 통해 사용자 가 소유하고 있는 각종 기기 및 다양한 OS의 종류에 구애받지 않고 콘텐츠의 OSMU를 실현할 수 있고, 콘텐츠의 연속성을 보장하여 보다 편리하게 교육용 콘텐츠를 이용할 수 있다.

\section{ABSTRACT}

The appearance of Intelligent mobile and home appliance increased the using of not only various multimedia contents but also educational contents. Especially the growth of smart device such as smart phone, smart pad and smart TV, provided the environment which everyone can use educational content anytime, anywhere, any device. However many smart devices are hard to reuse the various educational contents because the devices and mobile os policies are not unify. In this paper, we suggest the design of NeS(N-Screen e-learning system) in order to solve this problem. NeS is consisted of User Management, Educational Content Management, Content Convert System and Interactive Management System. In this system, we use the HTML5 language to assure interoperability in various Smart Device Environment. Through NeS, we can achieve Content OSMU(One Source Multi Use) in various device environment and assure the continuity of the contents for using the educational contents more easily.

푸 keyword : N-Screen, HTML5, 이기종 다매체, 이러닝 시스템, 콘텐츠 변환

\section{1. 서 론}

경량화 되고 고성능화된 모바일 기기에 모바일 $\mathrm{OS}$ 를 탑재한 스마트 디바이스인 스마트폰의 등장으로 인해 모 바일 단말은 획기적인 발전을 이룩했다. 이동성을 가지 고 언제 어디서나 인터넷에 접속할 수 있는 장점을 내세 운 스마트폰은 폭발적으로 성장하는 추세이다. 또한 스

* 준 회 원 : 성신여자대학교 컴퓨터학과 석사과정(주저자) zibeline@sungshin.ac.kr

** 정 회 원 : 성신여자대학교 IT학부 교수(교신저자) dseo@sungshin.ac.kr

*** 종신회원 : 성신여자대학교 IT학부 교수(교신저자) philhong@sungshin.ac.kr

[2012/05/23 투고 - 2012/05/30 심사(2012/06/09 2차) - 2012/09/05 심사완료]

눈 본 연구는 서울시 산학연 협력사업(PA100040)의 지원을 받 아 수행된 연구임
마트폰의 뒤를 이어, 좀 더 넓은 화면을 채택한 태블릿 $\mathrm{PC}$, 가전기기를 대표하는 $\mathrm{TV}$ 에 모바일 $\mathrm{OS}$ 를 접목한 스 마트 TV와 같은 하이브리드 기기들이 등장하면서 자연 스럽게 이들 단말들을 기반으로 하는 대용량 멀티미디어 콘텐츠들의 향유가 부각되기 시작했다. 이러한 변화에 따라 N-Screen의 개념이 확산되었다. 다음은 스마트 디바 이스들의 성장 전망을 나타낸 그림이다.

$\mathrm{N}-\mathrm{Screen}$ 은 기존에 존재하고 있던 $\mathrm{PC}, \mathrm{TV}$ 등의 전자기 기를 기반으로 하여 최근에 등장한 고성능화된 모바일 단말인 스마트폰 및 태블릿 $\mathrm{PC}$, 내비게이션 등으로 그 적용 범위를 넓혀가고 있다. 이러한 멀티 디바이스 환경 이 확대됨에 따라 언제 어디서나 인터넷에 연결된 고성 능 모바일 단말을 사용할 수 있다는 장점을 이용하여 이 러닝 서비스 또한 변화하기 시작했다. N-Screen 환경을 기반으로 하는 다양한 형태의 이러닝 서비스들의 등장은 고성능·지능화된 다양한 스크린 환경에서의 학습을 가능 


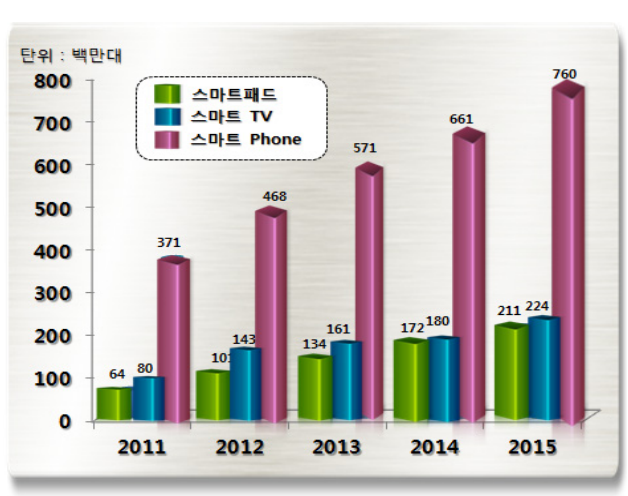

(그림 1) 스마트 디바이스의 성장 전망

하게 했다.

이러한 환경 변화로 인해 새로운 형태의 교육 콘텐츠들 이 등장하게 되었지만 이기종 다매체간의 하드웨어적, 소 프트웨어적 단절로 인해 야기되는 문제로 콘텐츠를 이용 하는 데 있어 콘텐츠의 중복구매로 인한 비용적인 문제와, 한번 구입한 콘텐츠를 다양한 기기에서 사용하지 못하는 재사용 문제와 같은 여러 가지 문제가 발생 하게 되었다.

이에 본 논문에서는 이러한 문제점을 해결하고자 다 양한 모바일 $\mathrm{OS}$ 를 탑재하고 있는 이기종 다매체 단말 환 경에서의 교육용 콘텐츠 공유를 가능하게 하는 시스템을 설계하고자 한다. 콘텐츠의 OSMU 및 연속적 재생 기능 을 구현하기 위해 본 논문에서는 최근 새로운 웹 표준으 로 대두되고 있는 HTML5 언어를 이용한다. 본 시스템을 통해 단말 제조사 및 단말에 탑재된 모바일 $\mathrm{OS}$ 에 관계없 이 다양한 종류의 교육용 콘텐츠를 사용하는 기기 및 환 경에 맞게 제공 받을 수 있다.

본 논문의 구성은 다음과 같다. 1 장의 서론에 이어 2 장의 관련연구에서는 N-Screen 환경 기반의 이러닝 시스템 설계 에 관련된 기술들에 대해 설명하고, 3장에서는 현재 N-Screen 환경 내에서 교육 콘텐츠를 이용하는 데 있어 발생 하는 문제점에 대해 논한다. 4장에서는 N-Screen 환경을 기 반으로 하는 이기종 다매체에 대응되는 이러닝 시스템에 대 한 분석 및 설계를 제시하고 프로토타이핑에 관하여 논한다. 마지막으로 5장의 결론을 끝으로 본 논문을 마무리 한다.

\section{2. 관련 연구}

\section{2. $1 \mathrm{~N}-$ Screen}

N-Screen은 무선망과 인터넷의 초고속화와 함께 비디

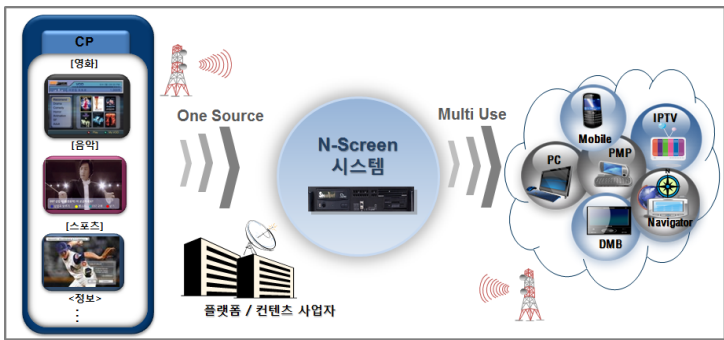

(그림 2) N-Screen의 개요도

오 스트리밍, 모바일 방송, IPTV 등 방통융합 환경에서의 멀티미디어 콘텐츠가 보편화되고, 이종의 접속 망과 다 양한 성능의 단말이 혼재하는 융합 콘텐츠 환경에서 스 마트폰, 태블릿 PC, PC 등의 다양한 단말에서 비디오, 음 악, 게임, 텍스트 데이터와 같은 콘텐츠를 끊김 없이 이 용할 수 있는 서비스를 일컫는다.[1] 다음 (그림 2)는 $\mathrm{N}$-Screen의 개요도 이다.

$\mathrm{N}-\mathrm{Screen}$ 을 서비스를 효과적으로 제공하기 위해서는 다양한 측면에서의 기술적 접목이 필요하다. N-Screen 서 비스를 실현하기 위해 대표적으로 필요한 기술들은 다음 표와 같이 구분할 수 있다. [2,3]

(표 1) N-Screen 서비스 제공을 위한 고려사항

\begin{tabular}{|c|c|}
\hline 분야 & 기술적 고려사항 \\
\hline $\begin{array}{l}\text { 단말 } \\
\text { 수용 } \\
\text { 기술 }\end{array}$ & $\begin{array}{l}\text { - 다양한 단말에서 서비스를 이용할 수 있도록 } \\
\text { 하기 위한 개방형 } \mathrm{I} / \mathrm{F}(\mathrm{API}) \\
\text { - 클라우드 연동을 위한 서비스 가상화 } \\
\text { - 서버와 N-Screen 단말의 자동 연동 } \\
\text { - 홈단말의 개인 사용자 인식 } \\
\text { - HTML5 등의 표준 웹 수용 }\end{array}$ \\
\hline $\begin{array}{l}\text { 콘텐츠 } \\
\text { 및 } \\
\text { 서비스 } \\
\text { 제공 } \\
\text { 기술 }\end{array}$ & $\begin{array}{l}\text { - WAC, K-WAC등 오픈 마켓과의 연동 } \\
\text { - 스크린 동기화 등의 스크린 협업 } \\
\text { - 소셜 서비스를 위한 기존 SNS 연계 } \\
\text { - 웹과 TV 콘텐츠의 융합 } \\
\text { - 맞춤형 광고 제공 } \\
\text { - 멀티뷰를 위한 콘텐츠 제작/전송 }\end{array}$ \\
\hline $\begin{array}{l}\text { UI 및 } \\
\text { UX } \\
\text { 관련 } \\
\text { 기술 }\end{array}$ & $\begin{array}{l}\text { - Simple 리모콘, 음성/제스처 인식 기반 사용자 } \\
\text { 입력 장치 } \\
\text { - 직관적이고 시각적인 Rich UI/UX } \\
\text { - 스마트 단말을 이용한 서비스 제어 } \\
\text { - 사용자 맞춤형 시멘틱 검색 및 추천 }\end{array}$ \\
\hline $\begin{array}{c}\text { 플랫폼 } \\
\text { 기술 }\end{array}$ & $\begin{array}{l}\text { - 쉬운 인증 및 결제(NFC, 신용카드 등) } \\
\text { - ID/콘텐츠/과금/메타정보/인증/단말의 통합관리 } \\
\text { - DRM, CAS, } \mathrm{FM} \text { (불법 콘텐츠 업로드 등 저작권 } \\
\text { 보호 } \\
\text { - 멀티 캐스팅 및 유무선 통합 QoS 보장 }\end{array}$ \\
\hline
\end{tabular}




\section{2 e-Learning}

이러닝이란 정보통신기술을 활용하여 언제, 어디서나, 누구나 원하는 수준별 맞춤형 학습을 할 수 있는 체제이 다. 이러닝은 전자적 수단, 정보통신, 전파방송기술을 활 용하여 이루어지는 학습으로 보는 광의의 의미와 인터넷 기반으로 학습자 상호작용을 극대화하면서 분산형의 열 린 학습공간을 추구하는 교육 형태를 나타내는 협의의 의미가 있다 (한국 사이버교육학회,2004).

이러닝은 웹 환경의 발전 및 진화의 흐름에 따라 끊임 없이 변화를 거듭했다. 참여, 공유, 개방을 표방하는 웹 2.0 의 등장으로 인해 이러닝은 기존에 구축 되어있던 오 프라인 교육에 대한 보조 학습 수단으로의 개념을 탈피 하고 새로운 형태의 교육 콘텐츠로서 주목받게 되었다. 최근에는 웹 2.0 에 이어 웹 3.0 의 개념이 등장하기 시작 하면서 이러닝 패러다임이 급격하게 변화하고 있다.

웹 2.0 의 개념이 결합된 이러닝 2,0 은 기존 이러닝이 내포하고 있었던 문제점을 웹 2.0에서 도입된 기술들을 통해 보완하는 방식으로 발전했다. 이러닝 2.0 은 자기주 도형 학습, 상호소통형 학습, 콘텐츠의 개인화 같은 특징 을 가진다. [4]

또한, 이러닝 2.0 의 특징이 스마트 기기가 가져오게 된 새로운 서비스 및 인터넷 패러다임에 부합되면서 스마트 기기를 이용한 이러닝이 주목받기 시작했다. 휴대성 및 이동성에 특화된 스마트폰과 스마트폰의 작은 스크린을 보완한 스마트 패드, 스마트 탭과 대표적인 가전제품으 로 최근 스마트화가 진행되고 있는 스마트 $\mathrm{TV}$ 등이 출시 되고, 이들을 이용한 신규 서비스들이 등장함으로서, 스 마트 기기를 기반으로 하는 다양한 이러닝 서비스가 증 가하고 있는 추세이다. [5]

\subsection{HTML 5}

HTML 5는 웹 문서를 만들기 위한 프로그래밍 언어인 HTML(HyperText Markup Language)의 차세대 웹 표준안 으로, 하나의 언어 (JavaScript), 하나의 데이터 모델 (XML, DOM), 하나의 레이아웃 (CSS)을 통일적으로 제공 하여 텍스트, 오디오, 비디오 등을 통합 제공해준다. 현재 월드 와이드 웹 컨소시엄 (W3C)과 웹 하이퍼텍스트 애플 리케이션 기술 워킹 그룹(WHATWG)에 의해 표준화가 진행 중이다. [6]

HTML 5는 다양한 스마트 기기의 통합 환경을 위한 유일한 해결책으로 인식 되어 이미 시장에서 급속한 확 산이 이루어지고 있다. 이것은 플랫폼 중립 적이며 특정
디바이스에 종속되지 않게 활용할 수 있다는 웹의 특징 때문이며, 기존 유선 환경을 넘어 스마트폰 환경으로 확 산되고 있고 향후에는 스마트TV 등을 포함한 스마트기 기 환경에서의 공통 콘텐츠 플랫폼으로 활용될 것으로 전망 되고 있다.[7] 구글 및 애플, MS와 같은 영향력 있 는 벤더들이 자사의 웹 브라우저 에서 HTML 5 를 적극 지원 하도록 함으로써 이기종 다매체간의 다양한 멀티미 디어 콘텐츠의 상호운용의 실현에 이용될 수 있을 것으 로 전망된다.

\section{N-Screen 환경 내 이러닝의 문제점}

N-Screen 환경이 확산되면서 대용량 멀티미디어 콘텐 츠의 유통이 활발해졌다. 이러한 변화는 대용량 멀티미디 어 콘텐츠를 기반으로 하는 이러닝 서비스 환경에도 영향 을 미치게 되었다. 사용자들은 다양한 스마트 디바이스를 통해 여러 가지 형태의 이러닝 콘텐츠들을 네트워크에 접 속할 수 있는 환경이라면 언제 어디서나 이용할 수 있게 되었다. 그러나 이러한 환경들이 확산 되고 있음에도 불 구하고, 이러닝을 서비스 하는 데 있어 N-Screen을 구성하 는 단말들의 기기적인 차이와 탑재 되어있는 소프트웨어 들의 차이로 인해 여러 가지 문제가 발생하게 되었다.

첫째로, 제조사별 기기 및 모바일 OS 사업자간의 호 환이 이루어지지 않아 한 번 구입한 콘텐츠를 공유하지 못해 사용하고 있는 기기마다 중복구매 해야 하는 비용 에 대한 문제가 발생한다.

둘째로, 각 기기 및 모바일 OS별로 최적화된 콘텐츠를 제공하지 못해 구입한 콘텐츠를 이용할 수 없거나, 특정 기기에서만 이용해야 하는 가용성의 문제를 들 수 있다.

셋째로, 연속성이 보장되어야 하는 교육용 콘텐츠의 특성 상, 이동시에 이용하고 있던 교육용 콘텐츠의 중단 및 연속재생을 지원하는 이러닝 서비스가 존재하지 않 아, 교육 콘텐츠 이용 중단 후 다시 이용 하고자 할 때의 그 연속성이 보장되지 않는 문제가 있다. 모바일 단말과 $\mathrm{PC}, \mathrm{TV}$ 와 같은 고정 단말간의 불연속성 또한 이와 같은 문제에 속한다고 볼 수 있다.

이러한 문제점들은 다수의 모바일 단말들을 보유하고 있는 이용자들이 각기 다른 환경에서 교육용 콘텐츠의 원활한 이용을 저해 하는 요인이 되고 있다.

본 논문에서 제시하는 시스템을 통해, 기존 이러닝 서 비스에서는 지원하지 않는 다양한 $\mathrm{OS}$ 환경을 지원함 과 동시에 콘텐츠의 재 사용성을 극대화하고, 콘텐츠 연속 재생 및 기기 변경의 지원과 같은 효과를 기대할 수 있다. 


\section{4. $\mathrm{NeS}(\mathrm{N}-\mathrm{Screen}$ e-Learning $\mathrm{Sys}^{-}$tem) 설계 방안}

\section{1 시스템 구성}

본 논문에서 제안하고자 하는 $\mathrm{NeS}$ 는 크게 이용자 학 습 관리와, 교육 콘텐츠 관리, 콘텐츠 변환 및 양방향 처 리로 구성된다. (그림 3)은 $\mathrm{NeS}$ 의 전체 구성을 나타낸 구 성도이다.

사용자는 본 서비스를 통해 단말 제조사 및 단말에 탑 재된 모바일 $\mathrm{OS}$ 에 관계없이 다양한 종류의 교육용 콘텐 츠를 사용하는 기기 및 환경에 맞게 제공 받을 수 있다. 다음은 $\mathrm{NeS}$ 의 구성 요소에 대한 설명이며, (표 2)는 해당 구성 요소의 세부 내역을 나타낸 표이다.

\subsection{1 이용자 학습 관리}

이용자 학습 관리는 사용자가 직접적으로 이용하게 되는 서비스로서 웹 서비스, 스마트폰, 스마트 TV 어플

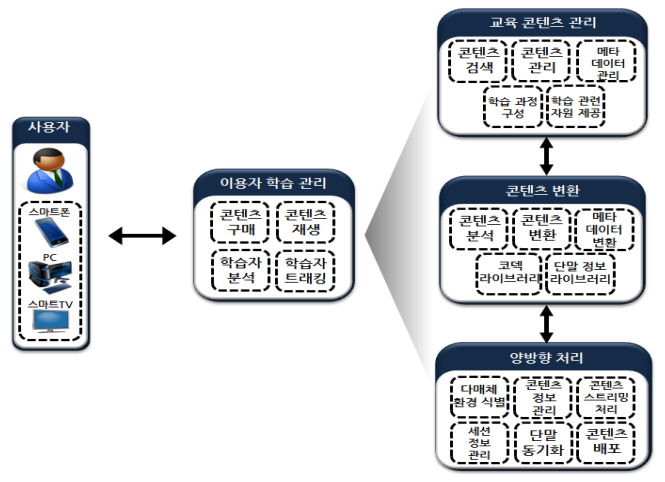

(그림 3) $\mathrm{NeS}$ 개요도

리케이션과 같은 형태로 구성될 수 있다. 이용자 학습 관 리에서는 기본적인 콘텐츠의 구매 및 재생 기능을 지원 한다. 뿐만 아니라 교육 콘텐츠를 이용하는 학습자의 강 의 이용 행태 및 경향 분석 등을 통한 학습자 분석에 대 한 통지 기능과 월별 학습 성취도, 학습 단계별 성취도와 같은 학습자 트래킹 기능을 수행한다.

(표 2) N-Screen 기반 이러닝 시스템 구성요소별 상세

\begin{tabular}{|c|c|c|}
\hline 대분류 & 소분류 & 상세 내역 \\
\hline \multirow{4}{*}{$\begin{array}{l}\text { 이용자 } \\
\text { 학습 관리 }\end{array}$} & 콘텐츠 구매 & • 교육 콘텐츠의 구매 \\
\hline & 콘텐츠 재생 & - 다양한 형태의 멀티미디어 교육 콘텐츠를 시스템에서 제공하는 뷰어를 통해 재생 \\
\hline & 학습자 분석 & - 학습자의 학습 양식, 프로필 및 요구 사항등의 분석 \\
\hline & 학습자 트래킹 & - 학습과정 및 진도 추적, 학습 활동성 평가, 강의평가 수행 \\
\hline \multirow{5}{*}{$\begin{array}{l}\text { 교육 } \\
\text { 콘텐츠 } \\
\text { 관리 }\end{array}$} & 콘텐츠 검색 & • 등록되어있는 교육 콘텐츠의 검색 \\
\hline & 콘텐츠 관리 & • 콘텐츠의 등록, 수정 및 삭제의 기본 관리 수행 \\
\hline & 메타데이터 관리 & $\begin{array}{l}\text { - 콘텐츠 타이틀, 등록일자, 저작자와 같은 콘텐츠의 부가 정보를 등록 및 수정, 삭제하는 } \\
\text { 관리 기능 수행 }\end{array}$ \\
\hline & 학습과정 구성 & • 학습 이수 영역 및 세부 수강 과목에 대한 학습 과정 구성 \\
\hline & $\begin{array}{l}\text { 학습 관련 } \\
\text { 자원 제공 }\end{array}$ & • 강의 계획서, 보조 자료와 같은 학습에 필요한 부수적인 자료 제공 \\
\hline \multirow{5}{*}{$\begin{array}{l}\text { 콘텐츠 } \\
\text { 변환 }\end{array}$} & 콘텐츠 분석 & - 콘텐츠의 분류, 파일 타입, 인코딩 형식 등의 콘텐츠에 대한 전반적인 정보 분석 \\
\hline & 콘텐츠 변환 & • 사용자의 기기에서 사용할 수 있는 형태로 콘텐츠를 변환 \\
\hline & 메타데이터 변환 & - 교육 콘텐츠 관리에서 전달받은 메타데이터를 변환된 콘텐츠와 맞게 변환 및 결합 \\
\hline & 코덱 라이브러리 & • 콘텐츠 인코딩/디코딩에 사용되는 코덱과 해당 API 포함 \\
\hline & $\begin{array}{l}\text { 단말 정보 } \\
\text { 라이브러리 }\end{array}$ & - 입력받은 사용자 기기에서 사용 가능한 확장자 및 코덱 정보 포함 \\
\hline \multirow{6}{*}{$\begin{array}{l}\text { 양방향 } \\
\text { 처리 }\end{array}$} & 다매체 환경 식별 & $\begin{array}{l}\text { - 사용자가 서비스에 접근한 단말 타입 및 정보 파악 } \\
\text { - 사용자가 서비스에 접근한 단말의 OS나 제어 시스템의 정보 파악 } \\
\text { - 해당 시스템에서 유효한 콘텐츠의 타입 파악 }\end{array}$ \\
\hline & 콘텐츠 정보 관리 & - 사용자의 콘텐츠 재생목록 및 재생 중단 콘텐츠 목록, 중단 시점의 관리 \\
\hline & $\begin{array}{c}\text { 콘텐츠 } \\
\text { 스트리밍 처리 }\end{array}$ & • 콘텐츠를 사용자에게 전달하기 위한 스트리밍의 처리 및 제어 \\
\hline & 세션 정보 관리 & - 세션 연결의 제어 및 관리, 제어권 이동의 수행 등 \\
\hline & 단말 동기화 & • 콘텐츠 전송을 위해 단말과 서버 연결 및 통신 프로토콜 제어 \\
\hline & 콘텐츠 배포 & - 콘텐츠 전송 서버에서 사용자 단말에 맞게 변환된 콘텐츠를 스트리밍을 통해 배포 \\
\hline
\end{tabular}




\subsection{2 교육 콘텐츠 관리}

교육 콘텐츠 관리는 이용자 학습 관리를 통해 학습자 에게 제공될 교육 콘텐츠 및 기타 부수적인 자료들의 제 공에 관련된 사항을 관리한다. 또한 데이터베이스에 등 록 되어있는 콘텐츠를 기반으로 한 교육 과정들의 생성, 수정 및 삭제와 같은 기본적인 관리를 담당하고 관리한 다. 교육 콘텐츠에 추가되는 부가적인 정보를 표시하기 위한 메타 데이터의 형식, 내용 등을 작성하고 편집 및 삭제 등의 관리 또한 담당한다. 메타데이터는 기본적으 로 XML의 형태로 작성되어 그 가용성과 상호호환성을 높인다.

\subsection{3 콘텐츠 변환}

콘텐츠 변환에서는 먼저 교육 콘텐츠 관리에 연결된 콘텐츠 관리 데이터베이스에 등록된 콘텐츠들을 사용자 의 선택에 따라 전송을 받는다. 양방향 처리로부터 전달 받은 MAC 주소 혹은 기기의 일련번호나 IEMI번호를 통 해 사용자 이용 기기를 파악하고 매치시킨 후 코덱 라이 브러리에 저장되어 있는 코덱을 이용하여 사용자가 콘텐 츠를 이용하고자 하는 환경에 맞게 변환한다. 콘텐츠의 종류는 이미지, 텍스트, 오디오, 비디오 파일등으로 구분 할 수 있으며 이용될 수 있는 확장자와 콘텐츠의 인코딩 및 디코딩에 활용될 수 있는 방식 및 동영상을 변환할 때 사용되는 코덱의 종류는 다음 표와 같다.

(표 3) 콘텐츠 확장자 및 코덱 분류

\begin{tabular}{|c|c|c|}
\hline \multirow{2}{*}{$\begin{array}{l}\text { 콘텐츠 } \\
\text { 타입 }\end{array}$} & \multicolumn{2}{|r|}{ 분류 } \\
\hline & $\begin{array}{l}\text { 사용 가능 } \\
\text { 확장자 }\end{array}$ & $\begin{array}{l}\text { 사용 가능 코덱 } \\
\text { (인코딩 방식)) }\end{array}$ \\
\hline 텍스트 & txt & UTF-8, EUC-KR, ANSI \\
\hline 이미지 & $\begin{array}{l}\text { jpg, png, bmp, } \\
\text { gif }\end{array}$ & jpg, png, bmp, gif \\
\hline 오디오 & $\begin{array}{l}\text { wav, mp3, m4a, } \\
\text { ogg, wma, flac }\end{array}$ & $\begin{array}{l}\text { wav, mp3, aac, avc, ogg, } \\
\text { wma, flac }\end{array}$ \\
\hline 비디오 & $\begin{array}{c}\text { asf, avi, ts, tp, } \\
\text { wmv, mkv, mp4 }\end{array}$ & $\begin{array}{l}\text { 영상 : H.264, DivX, Xvid, } \\
\text { MPEG, avi 코덱 등. } \\
\text { 음성 : aac, avc 등. }\end{array}$ \\
\hline
\end{tabular}

콘텐츠 변환 시 콘텐츠 관리에서 필요한 코덱 라이브 러리 및 단말 라이브러리를 이용하여 단말에 최적화 된 형태로 콘텐츠를 변환한다. 또한 메타데이터를 함께 변 환함으로써 콘텐츠를 이용할 때 부가 정보들을 사용자에 게 표시할 수 있도록 한다.

\subsection{4 양방향 처리}

양방향 처리는 사용자 접근 기기 환경 파악을 수행하 고 콘텐츠 변환에서 변환된 사용자 선택 콘텐츠를 전달 받아, 사용자가 선택한 기기로 배포 한다. 또한 콘텐츠를 스트리밍 할 때 프로토콜 및 기타 전송 정보의 제어와 재 생기기를 변경할 때 처리되는 세션의 저장하고 관리한 다. 그리고 재생 중단 콘텐츠에 대한 정보들을 관리하는 역할을 담당한다. 양방향 처리에서는 다양한 사용자 기 기의 접속을 판별하여 그 기기의 타입과 그 모델명을 분 석한다. 그리고 해당 기기의 모델명 및 타입 정보를 통해 탑재되어 있는 모바일 OS를 분석하여 해당 OS에서 지원 하는 콘텐츠 의 형태 및 확장자, 사용 코덱과 같은 콘텐 츠 변환 및 전송에 관한 정보를 추출한다. 또한 콘텐츠 송출 시 해당 OS에서 지원하는 스트리밍 형식을 통해 콘 텐츠 를 배포하고, 제어를 수행한다.

양방향 처리에서 이루어지는 콘텐츠의 재생 중단 시 점의 추출 및, 중단 시점부터의 재생을 구현하기 위해 HTML5 및 DOM(Document Object Model)을 이용한 (표 3)과 같은 함수를 통해 콘텐츠가 일시정지 되었을 때 콘 텐츠 중단 시점을 추출한 후 양방향 처리 서버에 전달하 고, 사용자 단말에서 콘텐츠를 다시 중단 시점부터 재생 할 수 있도록 하였다.

\section{(표 3) 콘텐츠 중단 시점 추출 함수}

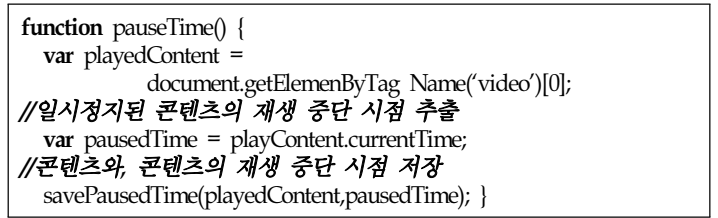

또한 (표 4)와 같은 함수를 통해 콘텐츠를 재생할 때 해당 콘텐츠가 재생 중단 되었는지를 확인한 후, 중단 콘 텐츠이면 양방향 처리에 저장되어 있는 재생 중단 시점 을 불러와 그 시점부터 재생할 수 있게 하였다.

\section{(표 4) 콘텐츠 재생 함수}

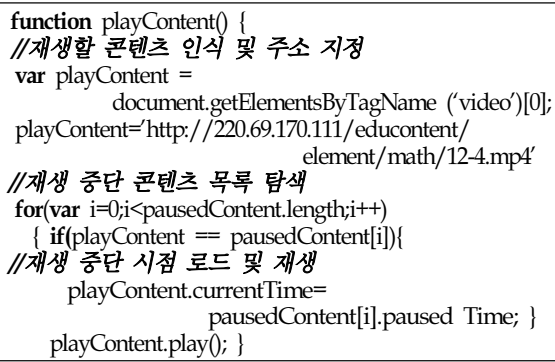




\section{2 시스템 플로우차트}

$\mathrm{N}-\mathrm{Screen}$ 환경 기반 이러닝 시스템에서 사용자가 수행 할 수 있는 프로세스는 크게 콘텐츠의 재생과 및 재생 기 기의 변경을 들 수 있다. 예를 들어, 사용자가 $\mathrm{PC}$ 에서 콘 텐츠의 재생을 수행하다 콘텐츠 재생기기를 스마트폰으 로 변경하는 것과 같은 경우를 들 수 있다. 각 프로세스 에 대한 플로우차트는 다음과 같다.

\subsection{1 콘텐츠 재생}

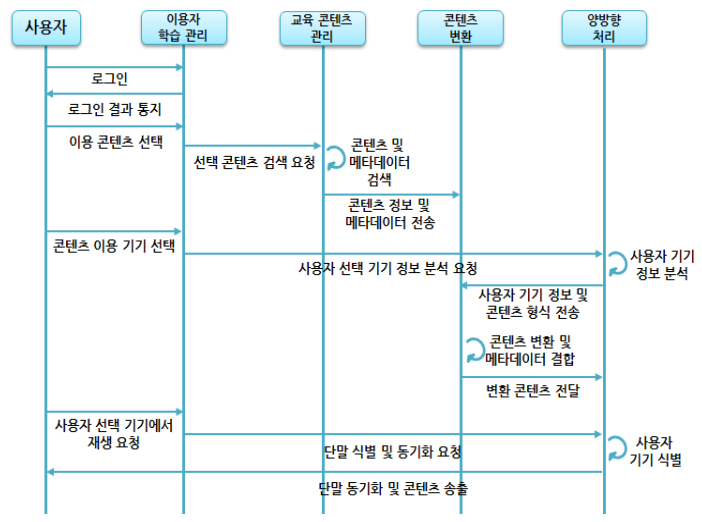

(그림 4) 콘텐츠 재생 플로우차트

사용자가 이용하고자 하는 콘텐츠의 종류(텍스트, 이 미지, 음성, 동영상 등의 포맷)을 선택하게 되면 이 정보 를 교육 콘텐츠 관리로 전달하고, 서버에 연결 되어 있는 콘텐츠 관리 데이터베이스를 검색한다. 검색이 끝나면 데이터베이스에 저장되어 있는 콘텐츠 와, 해당 콘텐츠 와 연계 되어 있는 메타데이터를 불러 와서 콘텐츠 변환 으로 전달한다.

다음으로 콘텐츠의 재생을 수행할 이용 기기를 선택 하면 이를 양방향 처리로 전달한다. 양방향 처리는 사용 자 기기의 종류, $\mathrm{OS}$ 의 타입, 사용 가능한 파일 확장자 등 의 정보를 분석한 후 콘텐츠 변환으로 전송한다. 콘텐츠 전송에서는 선택한 콘텐츠 및 메타 데이터를 기기 정보 와 매치해서 사용자가 선택한 기기에서 이용할 수 있는 형태로 변환하고, 변환된 콘텐츠는 양방향 처리에 전달 된다.

사용자가 사용하고자 하는 기기에서 해당 콘텐츠의 재생을 요청하면 양방향 처리에서는 재생을 요청한 기기 를 확인하고, 재생하고자 하는 콘텐츠를 검색한 후 스 트리밍을 통해 콘텐츠를 송출하게 된다.

\subsection{2 재생기기 변경}

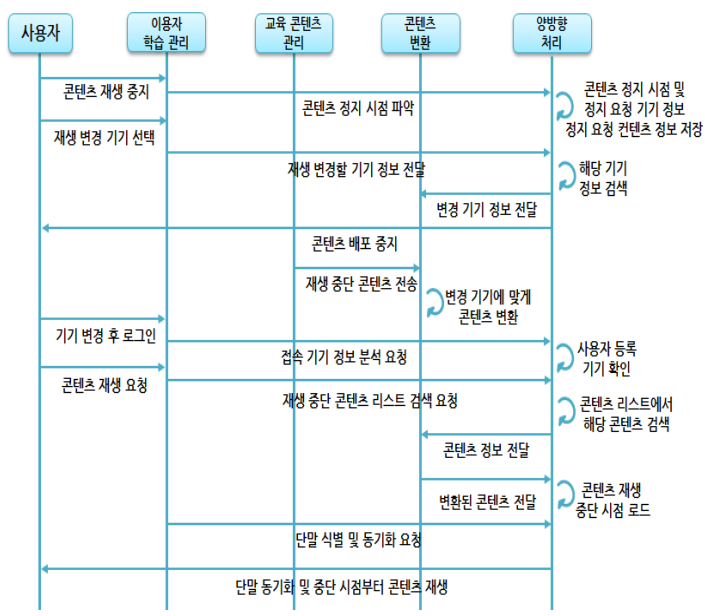

(그림 5) 재생기기 변경 플로우차트

사용자가 재생하고 있는 콘텐츠를 다른 기기로 변경 하기 위해 현재 재생하고 있는 콘텐츠의 재생의 중지를 요청한다. 콘텐츠 뷰어가 콘텐츠 재생 중지 요청을 받으 면 재생 정지 시점을 분석 후 양방향 처리로 전송한다. 양방향 처리는 재생 중지 시점 및 중지 요청 기기 정보, 콘텐츠의 정보를 저장한다. 또한 재생을 변경할 기기를 선택하면 해당 기기의 정보를 검색하여 콘텐츠 변환으로 전송한다. 해당 정보를 전송 받은 콘텐츠 변환에서는 사 용자가 변경을 요청한 기기에 맞게 콘텐츠를 변환하게 된다.

사용자가 기기를 변경하면 양방향 처리에서는 현재 서비스에 접속한 기기가 사용자의 기기로 등록된 기기인 지, 사용자가 연속 재생을 요청한 기기가 맞는지 확인을 한다. 기기 확인이 끝난 후 중단한 콘텐츠의 재생을 요청 하면 양방향 처리에 저장되어 있는 재생 중단 콘텐츠 리 스트 검색을 요청한다. 검색이 끝나면 콘텐츠 변환에서 변환된 해당 콘텐츠를 양방향 처리로 전달한다. 양방향 처리는 해당 콘텐츠의 중단 시점을 로드 한 후 서비스에 접속한 단말의 식별 및 동기화를 요청한다. 동기화가 끝 나면 로드한 콘텐츠의 중단 시점부터 콘텐츠 스트리밍을 시작하게 된다.

\section{3 알고리즘}

시스템 플로우차트를 바탕으로 한 $\mathrm{NeS}$ 의 알고리즘은 다음과 같다. 


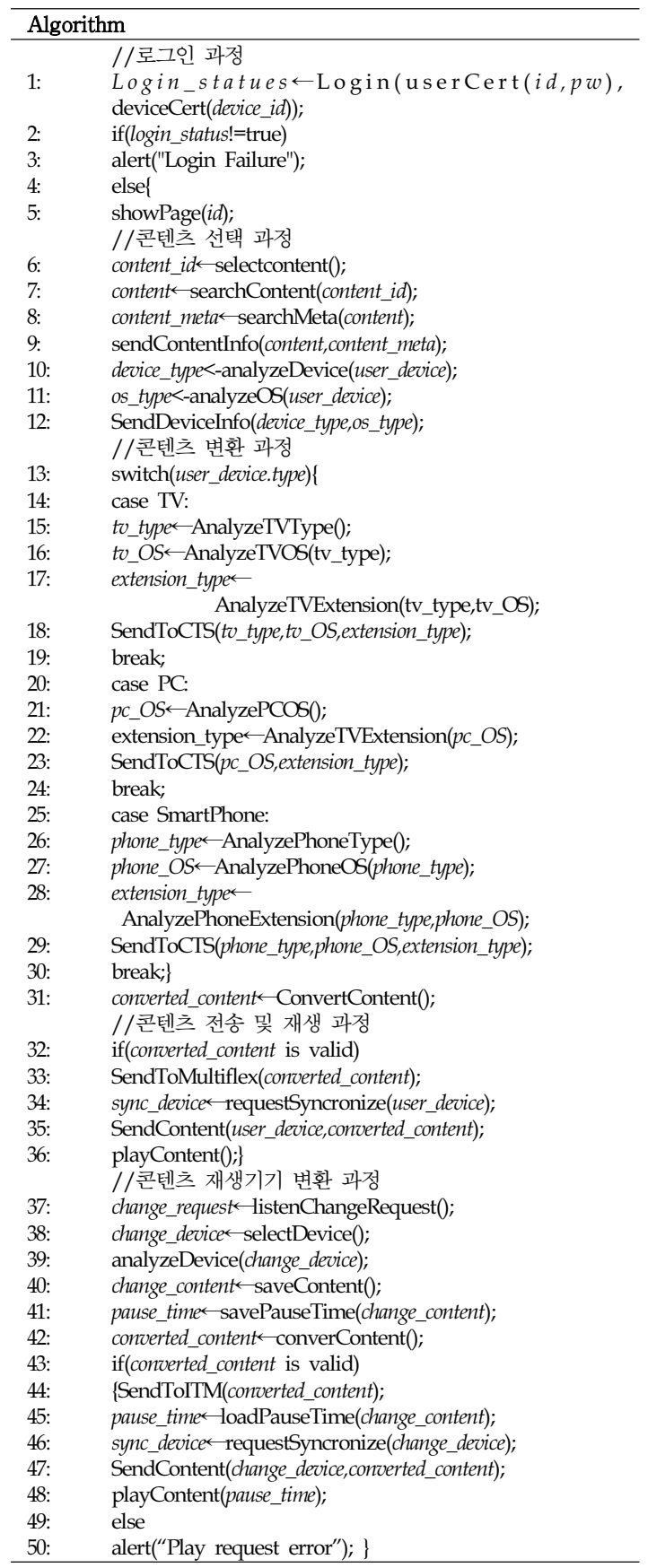

\section{4 프로토타이핑}

$\mathrm{NeS}$ 는 $\mathrm{PC}$ 및 SmartPhone 기반의 환경에서 구현되었 다. $\mathrm{PC}$ 는 Windows 7 운영체제에서, SmartPhone은 애플의

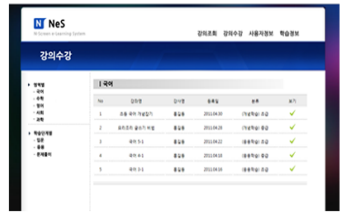

(1)

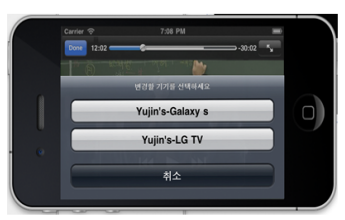

(3)

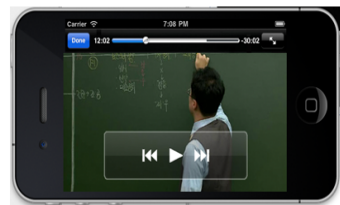

(2)

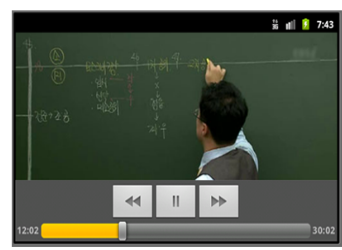

(4)
〈그림 6〉 $\mathrm{NeS}$ 프로토타이핑 화면

iPhone과 구글의 Android 환경에서 구현되었다. 언어는 각각 JSP, Objective-C, Android Java, 그리고 HTML 5 를 이용하였다. 웹 환경으로는 Apache Tomcat 6.0 을 지원한 다. DBMS 로는 MySQL 5.5를 사용하고, 구현 툴로는 각 각 XCode(iOS)와 Eclipse(Android, PC)를 이용하였다. 다 음 (그림 6)은 본 논문에서 제안하는 시스템을 플로우 차 트에 따라 적용하여 구현한 화면본이다.

(그림 6)의 (1)는 Windows 7 운영체제에서 JSP로 구축 된 PC 기반의 웹 서비스 화면을 보여준다. 사용자가 가 장 일반적으로 접근할 수 있는 서비스로, 콘텐츠의 구매 및 재생, 사용자 트래킹과 같은 서비스들을 지원하는 화 면이다. (2)는 iPhone 환경에서 콘텐츠를 재생하고 있는 화면이다. 그림 6의 (2)와 같이 콘텐츠를 일시정지 하게 되면 (3)의 화면에서 보이는 사용자 선택 팝업창이 뜨게 되고, 여기서 사용자는 재생을 이동할 기기를 선택할 수 있다. 사용자가 재생 이동 기기를 선택하면 현재 재생중 인 기기에서는 콘텐츠의 재생을 중단하고, 재생 중단 시 점을 양방향 처리로 전달한다. 그림 6의 (4)은 콘텐츠를 사용하고자 하는 기기를 변경한 후 중단 시점부터 다시 재생 하는 화면이다. 이와 같은 과정을 통해 기기의 타입 및 탑재 시스템에 관계없이 콘텐츠의 원활한 재생이 가 능하다.

\section{5. 결론 및 향후 연구}

본 논문에서는 N-Screen 환경 내에서 스마트 기기의 종류 혹은 탑재 OS 및 시스템에 제약 없이 콘텐츠의 OSMU를 실현할 수 있는 이러닝 시스템을 설계하였다. 
본 시스템을 통해 이용자들은 개인이 소지하고 있는 TV, $\mathrm{PC}$, 스마트폰, 태블릿 $\mathrm{PC}$ 등의 모바일 $\mathrm{OS}$ 를 차용하고 있 는 다양한 기기의 환경의 제약 없이 한번 구매한 콘텐츠 들의 재사용성을 높일 수 있다.

본 논문에서 제안한 N-Screen 환경 기반의 이러닝 시 스템은 기존의 다양한 멀티미디어 콘텐츠 서비스 및 이 러닝 서비스들이 특정 회사 및 소프트웨어 벤더의 제품 환경 내에서만 재사용이 가능했던 문제점을 해결할 수 있다는 점에서 스마트 기기 및 N-Screen 서비스의 확산에 따른 서비스 활용을 기대할 수 있다. 기존 이러닝 서비스 들과는 다르게 여러 기기에서의 콘텐츠의 재사용성을 지 원하고, 재생 중단 시점부터의 재생 기능을 지원 하며, 콘텐츠 재생 기기의 변경을 지원함으로써 점점 확대되고 있는 스마트 디바이스 및 N-Screen 환경 내에서의 활발한 교육 콘텐츠의 이용 및 언제 어디서나 제약 없이 다양한 단말로 콘텐츠의 이용 가능성을 타진하여 콘텐츠의 다중 기기 이용에 대한 비용 및 활용에 대한 문제점을 해결할 수 있을 것으로 예상된다.

향후에는 본 논문에서 제안한 시스템에서 이용자 들에 게 신뢰성을 보장 및 개인정보의 보안성을 제공 하기 위 한 방안으로 사용자 인증과 단말 인증, 그리고 콘텐츠의 인증을 제공할 수 있는 방안을 연구할 예정 이다. 또한
HTML 5 언어를 이용하여 멀티미디어 콘텐츠의 효율적인 스트리밍의 제어 및 콘텐츠에 부가적으로 표현되는 메타 데이터의 효율적 적용 방안에 대하여 연구할 예정이다.

\section{참 고 문 헌}

[1] 김윤화 (2010). N-Screen 전략 및 추진 동향 분석. 정보통신정책연구원 38(6), 442-448.

[2] 김진한 (2012) N-Screen 서비스 모습 및 기술적 고 려 사항. 방송공학회지 17권 1호, 20-31.

[3] 권오철 (2012) 스마트폰 중심의 N- Screen 기술, 한국방송공학회지 제17권 1호, 8-92

[4] 지식경제부 기술표준원 (2009) 이러닝 표준화 로 드맵 개발 연구

[5] 임걸(2011) 스마트 러닝 교수학습 설계모형 탐구. 컴퓨터교육학회논문지 14(2), 33-45.

[6] 이은민 (2011) HTML5가 웹 환경에 미치는 영향. 정보과학회 논문지 제29권 6호, 55-60.

[7] Matthew B.Hoy(2011), HTML 5 : A MNNew Standard for the Web, Medical Reference Services Quarterly, Vol.30 No.1, 50-55 


\section{저 자 소 개}

\section{신 유 진(Yu-jin Shin)}

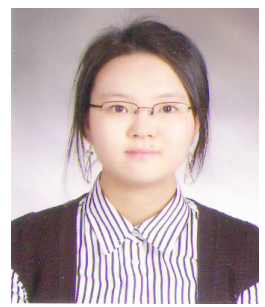

2011년 성신여자대학교 컴퓨터정보학부 졸업(학사)

2011년 현재 성신여자대학교 대학원 컴퓨터학과 석사과정

관심분야 : N-Screen, e-Learning 시스템, 프라이버시 보호.

E-mail : zibeline@sungshin.ac.kr

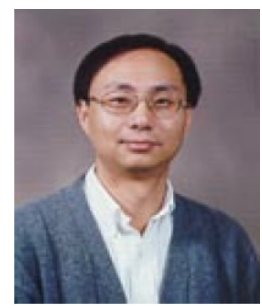

\section{서 동 수 (Dongsu Seo)}

1987년 중앙대학교 컴퓨터공학과(학사)

1989년 중앙대학교 컴퓨터공학과(석사)

1994년 Univ. of Manchester. Dept of Computation(박사)

1994년 1998년 전자통신연구원 선임연구원.

1998년 현재 성신여자대학교 IT학부 부교수

관심분야 : 소프트웨어공학, 정형기법, 정보보호기술

E-mail : dseo@sungshin.ac.kr.

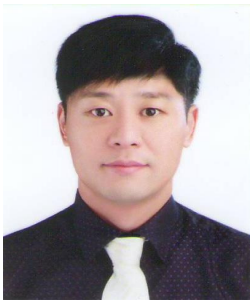

\section{홍 승 필 (Seng-Phil Hong)}

1993년 Indiana State University (학사)

1994년 Ball State University(석사)

1997년 Illinois Institute of Technology(박사수료)

2003년 KAIST (박사)

1997년 2005년 LG CMS Systems, Inc.

2005년 현재 성신여자대학교 IT학부 부교수

관심분야 : 접근제어, 통합인증, 정보보호 아키텍처, 유비쿼터스 보안, 프라이버시 보호.

E-mail : philhong@sungshin.ac.kr 